\title{
Responses of Forest Carbon Cycle to Drought and Elevated $\mathrm{CO}_{2}$
}

\author{
Jun-Lan Xiao, Feng Zeng, Qiu-Lan He, Yu-Xia Yao, Xiao Han and Wei-Yu Shi *
}

Citation: Xiao, J.-L.; Zeng, F.; He, Q.-L.; Yao, Y.-X.; Han, X.; Shi, W.-Y. Responses of Forest Carbon Cycle to Drought and Elevated $\mathrm{CO}_{2}$. Atmosphere 2021 12, 212. https://doi.org/10.3390/ atmos12020212

Academic Editors: Robert Baxter and Zhenzhong Zeng

Received: 12 December 2020

Accepted: 1 February 2021

Published: 4 February 2021

Publisher's Note: MDPI stays neutral with regard to jurisdictional claims in published maps and institutional affiliations.

Copyright: (c) 2021 by the authors. Licensee MDPI, Basel, Switzerland. This article is an open access article distributed under the terms and conditions of the Creative Commons Attribution (CC BY) license (https:/ / creativecommons.org/licenses/by/ $4.0 /)$.

\author{
Chongqing Jinfo Mountain Karst Ecosystem National Observation and Research Station, School of Geographical \\ Sciences, Southwest University, Chongqing 400715, China; swu0824@email.swu.edu.cn (J.-L.X.); \\ zoe369@email.swu.edu.cn (F.Z.); h13550800130@email.swu.edu.cn (Q.-L.H.); \\ swuyaoyuxia@email.swu.edu.cn (Y.-X.Y.); hx1997@email.swu.edu.cn (X.H.) \\ * Correspondence: shiweiyu@swu.edu.cn
}

\begin{abstract}
Forests play a pivotal role in mitigating global warming as an important carbon sink. Recent global greening trends reflect a positive influence of elevated atmospheric $\mathrm{CO}_{2}$ on terrestrial carbon uptake. However, increasingly frequent and intense drought events endanger the carbon sequestration function of forests. This review integrates previous studies across scales to identify potential global trends in forest responses to drought and elevated $\mathrm{CO}_{2}$ as well as to identify data needs in this important research field. The inconsistent responses of ecosystem respiration to drought contributes to the change of forest net $\mathrm{CO}_{2}$ exchange, which depends on the balance of opposite effects of warming and water stress on respiration. Whether $\mathrm{CO}_{2}$ fertilization can offset the effects of drought remains controversial, however, we found a potential overestimation of global $\mathrm{CO}_{2}$ fertilization effects because of increasing water stress and other limitations such as light and nutrients $(\mathrm{N}, \mathrm{P})$ as well as the possibility of photosynthetic acclimation.
\end{abstract}

Keywords: drought; elevated $\mathrm{CO}_{2}$; carbon cycle; water use; photosynthesis

\section{Introduction}

Forest ecosystems play a key role in the land-atmosphere system and provide wide ecological services and socio-economic benefits, including forest products, water regulation, biodiversity, soil protection, spiritual and inspirational needs, recreational activities and aesthetic value [1]. Additionally, climate is influenced and regulated by the interaction of forests and atmosphere through the exchange of energy, water, $\mathrm{CO}_{2}$ and other chemical compounds. Forests capture atmospheric $\mathrm{CO}_{2}$ and sequester it into their biomass and soil, and then release oxygen back to the atmosphere, which is the buffer against global warming. Forty-five percent of the terrestrial carbon is stored in forest biomass, organic matter and soil, which is one of the largest global carbon pools [1]. Terrestrial ecosystems take up around 3 petagrams $(\mathrm{Pg})$ of carbon emitted by human activities per year and capture nearly $30 \%$ of the $\mathrm{CO}_{2}$ released by logging and the combustion of fossil fuel [2] However, small shifts in the balance of forest ecosystem photosynthesis and respiration can lead to huge changes in the forest carbon cycle [3]. For example, elevated atmospheric $\mathrm{CO}_{2}$ promotes the rate of plant photosynthesis and enhances water use efficiency (WUE) by reducing stomatal conductance, which can offset part of carbon emissions without more water consumption [4].

The increase of plant photosynthetic rate by $\mathrm{CO}_{2}$ fertilization effects is considered one of the potential reasons for the observed global greening trends [5]. Higher WUE under elevated atmospheric $\mathrm{CO}_{2}$ makes plants more tolerant to water stress [6], however, frequent occurrence of extreme droughts and heat stress lead to the decline of forest productivity and biomass accrual by widespread tree mortality and wildfires [7]. The balance between drought-induced forest carbon loss and enhanced carbon uptake by $\mathrm{CO}_{2}$ fertilization depends on the severity and duration of droughts. The extent to which climate change affects forest carbon uptake and the interaction of drought and elevated $\mathrm{CO}_{2}$ on plant stress resistance is still unclear. We review the current understanding in the response of the forest 
carbon cycle to droughts and elevated $\mathrm{CO}_{2}$ and highlight a research gap in the interaction of drought and elevated $\mathrm{CO}_{2}$ on forest ecosystems. Since the global warming and severity of extreme events will continue to increase if greenhouse gas emissions are unmitigated, understanding the implications of the capacity of forests to sequester carbon under climate scenarios remains a pressing and crucial need.

\section{Drought and Forest Carbon Cycle}

Multiple concepts and indices of drought are applied in drought-related studies, which reflects the inconsistent indicators used to identify drought events. Climate change exacerbates the frequency, intensity and duration of extreme droughts, which directly impairs the carbon sequestration function of forest ecosystems. We clarify the definition of drought and discuss forest carbon cycle feedback to drought below.

\subsection{Drought Definition}

Kelly Redmond [8] generally describes drought as 'insufficient water to meet needs'. The moisture of terrestrial ecosystems is primarily provided by precipitation, but water demand comes from numerous places, for example, plant transpiration, land surface evaporation, agricultural irrigation and urban water use [9]. Therefore, although studies related to terrestrial ecosystem responses to droughts have a long history, there is no unified or standard definition for drought. Instead, researchers have characterized and defined drought in various ways according to the impacts of drought. For instance, drought can be described as precipitation decrease, low soil moisture, low water flow and plants facing water stress compared with normal conditions [10]. Multiple drought indices have been widely used to quantitatively define drought events, such as the Standardized Precipitation Index (SPI), the Standardized Precipitation-Evapotranspiration Index (SPEI), the Palmer Drought Severity Index (PDSI) and the self-calibrate PDSI (sc-PDSI). These indices require diverse input data and reflect different concepts of drought. For example, the SPI calculation only requires the time series of precipitation but does not consider the impact of evapotranspiration. SPEI was developed to compensate for this absence, which uses the same statistical method as SPI, but the input precipitation data is replaced with the difference between precipitation and potential evapotranspiration data (which is related to air temperature). Moreover, indices which perform well in specific regions may be unsuitable for other regions with different climate patterns and topographic conditions. Eslamian et al. [11] indicate that the PDSI performs better in wide plains than other indexes, such as in the United States and Australia. The Surface Water Supply Index (SWSI) is more suitable for the less-flat mountainous region [11]. A review focused on drought definition indicates that studies often confuse drought with dry conditions [10]. They calculated the SPEI for a group of drought-related studies, which did not quantify drought with specific indices, and found that $50 \%$ of drought events in those studies were defined as a normal condition by the SPEI $(-1<$ SPEI $<1)$. This surprising result may be attributed to the fact that the drought events in these studies had a shorter duration than the timescales of calculation [10].

Inconsistent definitions of drought may result in uncertainties in assessments of drought and drought-related ecological impacts. In addition to incorporating standard information (SPEI, PDSI, etc.) and statistically standardizing the definition of drought, it is also important to consider the response of ecosystems to drought. Smith [12] defined ecosystem-related extreme events as conditions in which changes in ecosystem functions and structures (such as productivity, nutrients, species composition and population) deviate from normal variability within a certain duration and area. Moreover, responses of ecosystems to extreme events include immediate and delayed effects [13], so the lagged response that happen after extreme events should also be considered. 


\subsection{Forest Carbon Cycle Feedbacks to Drought}

Seventy-eight percent of the changes of global gross primary production (GPP) in the past three decades are related to extreme events, while drought events account for $60-90 \%$ of these climate extremes [14]. The water limitation and high air temperature directly affect the carbon cycle of forests through plant responses to stress. Resistance strategies of plants coping with drought include changes in plants physiological traits [15]. At the leaf level, plant responses to drought are reflected in the reduced stomatal conductance and changes in photosynthetic and respiratory rates, which directly affects the carbon exchange between vegetation and the atmosphere (Figure 1). Granier et al. [16] demonstrated that soil moisture is the dominant limiting factor for forest carbon exchange in the 2003 Europe drought event because the GPP and ecosystem respiration (Re) both dropped sharply when the relative extractable soil water was lower than about 0.4 . Furthermore, the ecosystem feedbacks may aggravate the severity of drought because: (i) The evaporative cooling effect is reduced due to stomatal closure, so the high leaf temperature may cause heat stress; (ii) high-light stress aggravated by drought leads to the occurrence of photoinhibition or even photodamage; (iii) high temperature, high radiation and rising vapor pressure deficit (VPD) exacerbate drought by higher evapotranspiration [17].

Forest carbon uptake and sequestration can rapidly decrease after widespread tree mortality [18], and the impacts of the decline in forest net primary productivity (NPP) could last for decades. Moreover, the decomposition process of the remnant biomass and underground dead roots releases stored carbon back to the atmosphere (Figure 1c), which can transform forests from carbon sinks into sources. Tree mortality is usually induced by the combination of multiple driving factors such as climate stress, diseases related to pests and pathogens, the stand life histories and fires [19]. Drought may serve as an inducer of the death of trees that are already under stress. The complexity of these drought-induced death mechanisms of trees makes the monitoring of tree mortality challenging. McDowell et al. [20] proposed three hypotheses about the mechanisms of drought-induced plant dieoff: (i) Hydraulic failure; (ii) carbon starvation, where water limitation-induced stomatal closure blocks carbon uptake; and (iii) biotic attack, where changes in populations of pests and pathogens under continuous warming lead to excessive tree damage and mortality. Hydraulic failure is considered to be the main factor leading to plant mortality related to drought $[21,22]$. The hydraulic failure hypothesis states that low soil water potential and soil hydraulic conductivity lead to an increase in the vapor pressure difference between leaves and atmosphere and the rising demand for evaporation. The xylem conduits and rhizosphere are filled with air so the plant hydraulic system cannot transport water from the rhizosphere to leaves resulting in plant tissues desiccation and death [20]. Droughtinduced tree mortality directly influences the land-atmosphere interaction because of the loss of vegetation function of exchanging water, energy and carbon.

Literature reporting forest carbon cycle responses to drought events in the last two decades is summarized in Table 1. The main causes of forest carbon budget variations related to drought are summarized below. First, increased tree mortality induced by drought explains large forest carbon storage loss in North America [17,23-25] and the Amazon [26-28]. As an example, in the 2010 Amazon drought event, an estimated $2.2 \mathrm{Pg}$ C storage was impacted [27] with a wider impact area than the 2005 event (1.6 Pg C [26]). This impact was mainly derived from the temporary suspension of biomass growth and tree mortality, which reversed the forest from a net carbon sink to source [27].

Second, studies from North America and Europe suggest drought duration and timing are crucial factors that affect the dynamics of forest carbon balance between gross primary productivity and ecosystem respiration [29-31]. For example, the increase of forest carbon uptake in a warm spring is eliminated by subsequent summer drought [29-32], and early warming-induced consumption of soil moisture may intensify the water stress and heating in summer [30]. In addition, the sensitivity of carbon flux to warming and drought varies among vegetation types [31,33]. Alaskan deciduous forests showed a much higher net carbon uptake during the growing season than evergreen forest because of leaf area increase 
in warm spring, which enlarged the difference of response to summer drought between deciduous forests and evergreen forests [33]. This result indicates a bigger contribution of $\mathrm{CO}_{2}$ uptake by deciduous forests in the northern hemisphere.

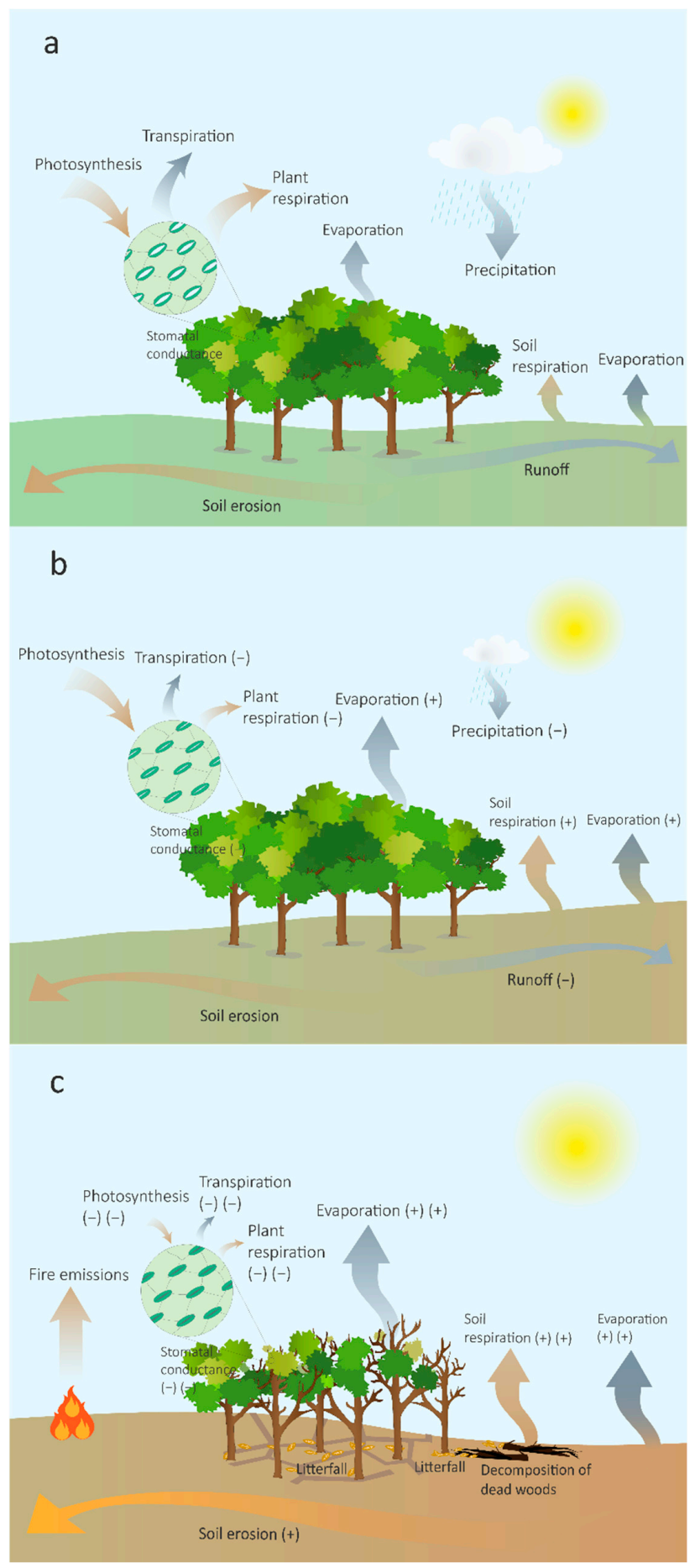

Figure 1. Forest carbon and water fluxes change as the intensity of drought increases. (a) Before drought events. (b) Moderate drought without tree mortality. (c) Severe drought with large biomass loss. Orange arrows show the carbon flux; blue arrows show the water flux. The magnitude of fluxes is indicated by the size of arrows. Numbers of $(+)$ and $(-)$ indicate that the degree of fluxes increase and decrease, respectively. Plant respiration includes leaf and stem respiration; soil respiration includes autotrophic soil respiration (roots) and heterotrophic respiration (litterfall, microbial community, soil organic matter, etc.). 
Third, the response of ecosystem respiration is expected to contribute to the uncertainty of the net $\mathrm{CO}_{2}$ exchange, because if Re and GPP decrease with a similar magnitude, the net primary productivity is expected to be unaffected by drought. The magnitude and direction of Re variation depend on duration and severity of drought and regional characteristics (such as soil moisture and vegetation types). Von Buttlar et al. [34] global study suggests that the direction of ecosystem respiration change depends on whether heat stress coincides with drought because heat and drought have the opposite impacts on Re. Re will keep stable if a warming-induced increase in Re is offset by water limitation. For example, ecosystem respiration in Alaskan forests increased during the 2004 summer drought because warming-caused increases in respiration exceeded the effects of limitations such as soil moisture and oxygen content [33]. Moreover, the European hot drought in 2003 led to a reduction in ecosystem respiration (autotrophic and heterotrophic respiration decreased) $[16,35,36]$. Ciais et al. [35] suggest that less carbon assimilation led to plant respiration decrease, and the negative effect of higher water stress on heterotrophic respiration exceed the positive effects of warming on it. Similar results were found in Lindroth et al. [37], they suggest that most forests in their study experienced a decline of net ecosystem productivity (decrease both in GPP and Re) in the 2018 summer drought across Northern Europe, and the forest carbon balance change was largely explained by decreased heterotrophic respiration and lack of precipitation.

Table 1. Summary of forest carbon cycle responses to drought events in recent two decades.

\begin{tabular}{|c|c|c|c|c|}
\hline Location & Period & Forest Carbon Variations & Causes & Reference \\
\hline $\begin{array}{l}\text { North American } \\
\text { boreal forest }\end{array}$ & 20th Century & - $\quad$ Restricted carbon uptake & $\begin{array}{ll}- & \text { Heat stress } \\
- & \text { Water deficit }\end{array}$ & Barber et al., 2000 [38] \\
\hline Europe & 2003 & $\begin{array}{ll}- & \text { Reduction of GPP } \\
- & \text { Reducing ecosystem respiration } \\
- & \text { Reduction of NPP }\end{array}$ & $\begin{array}{l}-\quad \text { Precipitation deficit } \\
\text { - } \quad \text { Extreme summer heat }\end{array}$ & $\begin{array}{l}\text { Ciais et al., } 2005 \text { [35] } \\
\text { Reichstein, M. et al., } 2007 \text { [36] } \\
\text { Granier et al., 2007 [16] }\end{array}$ \\
\hline Canada's boreal forests & 2000-2003 & $\begin{array}{l}-\quad 2000 \text { increase of NPP } \\
\text { - } \quad 2002-2003 \text { decrease of NPP }\end{array}$ & $\begin{array}{l}\text { - } \quad 2000 \text { warm spring and deep } \\
\text { soil moisture available } \\
\text { - } \quad 2002-2003 \text { water deficit }\end{array}$ & Kljun et al., 2006 [29] \\
\hline Interior Alaska & 2002-2004 & $\begin{array}{ll}- & \text { Reduction of GPP } \\
- & \text { Increase of ecosystem respiration } \\
- & \text { Reduction of NPP }\end{array}$ & $\begin{array}{ll}- & \text { Increased temperature } \\
\text { - } & \text { Increased vapor pressure deficit }\end{array}$ & Welp et al., 2007 [33] \\
\hline Amazon & 2005 & $\begin{array}{l}\text { - Total biomass carbon impact of } 1.2 \text { to } 1.6 \mathrm{Pg} \\
\text { - } \quad \text { Total carbon impact of } 2.2 \mathrm{Pg}\end{array}$ & - Water deficit & Phillips et al., 2009 [26] \\
\hline Amazon & 2005,2010 & $\begin{array}{l}\text { - Total carbon impact of } 2.2 \mathrm{Pg} \\
\text { - The temporary pause of biomass growth } \\
\text { - Loss of biomass }\end{array}$ & $\begin{array}{ll}- & \text { Tree mortality } \\
\text { - } & \text { Heterotrophic respiration }\end{array}$ & Lewis et al., 2011 [27] \\
\hline $\begin{array}{l}\text { Aspen forests in } \\
\text { North America }\end{array}$ & 2009-2011 & $\begin{array}{l}\text { Reduction in aboveground live } \\
\text { biomass in aspen forests }\end{array}$ & - $\quad$ Tree mortality & Huang and Anderegg, 2011 [17] \\
\hline Canada's boreal forests & 1965-2005 & $\begin{array}{ll}\text { - } & \text { Loss of the biomass carbon sink } \\
\text { - } & \text { Slowness of tree growth } \\
\text { Reduction of NPP }\end{array}$ & $\begin{array}{ll}- & \text { Water deficit } \\
- & \text { Tree mortality } \\
- & \text { Reduction of solar radiation }\end{array}$ & Ma et al., 2012 [23] \\
\hline Congo rainforest greenness & 2000-2012 & $\begin{array}{l}\text { - } \quad \text { Decreasing greenness } \\
\text { - } \quad \text { Decrease of photosynthetic capacity }\end{array}$ & $\begin{array}{l}\text { - } \quad \text { Water deficit } \\
\text { - } \quad \text { Increased temperature } \\
\text { active radiation }\end{array}$ & Zhou et al., 2014 [39] \\
\hline Amazon & 1985-2010 & $\begin{array}{l}\text { Downtrend of carbon accumulation } \\
\text { Decreasing rates of aboveground } \\
\text { biomass growth } \\
\text { - Shorter carbon residence times }\end{array}$ & - $\quad$ Tree mortality & Brienen et al., 2015 [28] \\
\hline United States & 2012 & $\begin{array}{l}\text { - Increase of NPP during warm spring } \\
\text { - } \quad \text { Decrease of NPP during summer drought }\end{array}$ & $\begin{array}{l}\text { - } \quad \text { Warm spring } \\
\quad \quad \text { Soil moisture deficit }\end{array}$ & Wolf et al., 2016 [30] \\
\hline Texas & 2011 & Loss of $9.5 \%$ tree cover & - $\quad$ Tree mortality & Schwantes et al., 2017 [24] \\
\hline
\end{tabular}


Table 1. Cont.

\begin{tabular}{|c|c|c|c|c|}
\hline Location & Period & Forest Carbon Variations & Causes & Reference \\
\hline Global & Site-dependent & $\begin{array}{l}\text { Reduction of GPP and Re, neutral NPP } \\
\text { response (drought without heat) } \\
\text { Reduction of GPP and NPP, increase } \\
\text { of Re (drought with heat) }\end{array}$ & - $\quad$ Drought and heat & von Buttlar et al., 2018 [34] \\
\hline California & 2001-2015 & - $\quad$ Loss of $188.4 \mathrm{Tg}$ carbon storage & $\begin{array}{ll}- & \text { Tree mortality } \\
\text { - } & \text { Wildfire }\end{array}$ & Sleeter et al., 2019 [25] \\
\hline North American forests & Site-dependent & $\begin{array}{ll}\text { - } & \text { Reduction of NPP in deciduous forests } \\
\text { - } & \text { Neutral NPP variation in conifer forests }\end{array}$ & $\begin{array}{ll}- & \text { Seasons } \\
- & \text { Timing of drought }\end{array}$ & Xu et al., 2020 [31] \\
\hline Northern Europe & Dry summer of 2018 & $\begin{array}{ll}- & \text { Reduction of GPP } \\
- & \text { Reducing ecosystem respiration } \\
- & \text { Reduction of NPP }\end{array}$ & $\begin{array}{ll}-\quad & \text { Precipitation deficit } \\
\text { - } & \text { Heterotrophic respiration }\end{array}$ & Lindroth et al., 2020 [37] \\
\hline Site-dependent & Site-dependent & $\begin{array}{ll}- & \text { Fast decrease of GPP } \\
- & \text { Increase of WUE }\end{array}$ & $\begin{array}{ll}- & \text { Flash drought } \\
- & \text { High VPD } \\
\text { - } & \text { Low soil moisture }\end{array}$ & Zhang and Yuan, 2020 [40] \\
\hline Europe & 2018 & - $\quad$ Reduction of GPP & $\begin{array}{l}\text { Decrease of soil relative } \\
\text { extractable water content }\end{array}$ & $\begin{array}{l}\text { Gourlez de la Motte et al., } \\
2020[41]\end{array}$ \\
\hline Europe & 2018 & $\begin{array}{l}\text { - } \quad \text { Decrease of net } \mathrm{CO}_{2} \text { uptake } \\
\text { Increase of WUE }\end{array}$ & - $\quad$ Low soil moisture & Graf et al., 2020 [42] \\
\hline Europe & 2018 & $\begin{array}{ll}- & \text { Reduction of GPP } \\
- & \text { Reducing ecosystem respiration }\end{array}$ & - $\quad$ Low soil moisture & Smith et al., 2020 [43] \\
\hline
\end{tabular}

\section{Elevated $\mathrm{CO}_{2}$ Effect on Plants and Ecosystem}

Increasing global $\mathrm{CO}_{2}$ emissions positively stimulate the terrestrial gross primary productivity. Previous research on plant response to elevated $\mathrm{CO}_{2}$ has been developed across a range of scales, from leaf-level physiological experiments to satellite observations and the modelling of ecosystem response. We discuss $\mathrm{CO}_{2}$ fertilization effects from the perspectives of plant physiology to ecosystem response below.

\subsection{How Plants Respond to Elevated $\mathrm{CO}_{2}$}

Enriched atmospheric $\mathrm{CO}_{2}$ concentration interferes with plant physiological processes by reducing plant stomatal conductance, increasing water use efficiency and simultaneously enhancing photosynthesis rate and light use efficiency [4]. However, the $\mathrm{CO}_{2}$ fertilization effect is usually provisional since plants often acclimate to long-term elevated atmospheric $\mathrm{CO}_{2}$ with lower photosynthetic capacity. Furthermore, $\mathrm{CO}_{2}$ fertilization effects on plants may also be limited by other nutrients such as nitrogen $(\mathrm{N})$ and phosphorus $(\mathrm{P})$ [44].

\subsubsection{Stomatal Conductance}

The stomatal aperture is determined by the turgor pressure of the guard cell [45]. $\mathrm{CO}_{2}$ enrichment stimulates the guard cell by changing the ion channel activities or the ion composition inside and outside the cell membrane [46]. The response of stomata to atmospheric $\mathrm{CO}_{2}$ concentration varies among species, mainly owing to genetic traits and stomatal acclimation to humidity [4]. A reduced stomatal conductance $\left(g_{s}\right)$ under the enriched $\mathrm{CO}_{2}$ explains the decrease in leaf transpiration and the increase in water use efficiency, but it does not seem to limit photosynthesis. Whether reduced $g_{s}$ restricts photosynthesis is indicated by the ratio of intercellular to atmospheric $\mathrm{CO}_{2}$ concentration ( $\mathrm{Ci} / \mathrm{Ca}$ ). The decrease in stomatal conductance appears to limit plant photosynthesis if the value of $\mathrm{Ci} / \mathrm{Ca}$ in elevated $\mathrm{CO}_{2}$ is less than that in normal ambient $\mathrm{CO}_{2}$. However, Drake et al. [4] examined experiments with different species and found that there is no significant difference in $\mathrm{Ci} / \mathrm{Ca}$ between plants grown in ambient $\mathrm{CO}_{2}$ and elevated $\mathrm{CO}_{2}$, 
which proves that the reduced $g_{s}$ does not inhibit plant photosynthesis but enhances the WUE of plants.

\subsubsection{Photosynthesis}

The mechanism of plant photosynthesis stimulation by elevated $\mathrm{CO}_{2}$ is mainly driven by the activity of Ribulose-1,5-bisphosphate carboxylase/oxygenase (Rubisco). Rubisco catalyzes the carboxylation reaction to fix $\mathrm{CO}_{2}$ into 3-phosphoglyceric acid (3PGA) [47]. Since Rubisco has a low affinity for $\mathrm{CO}_{2}$ carboxylation and is not saturated at current $\mathrm{CO}_{2}$ concentration, elevated $\mathrm{CO}_{2}$ can stimulate and promote the carboxylation reaction [4]. However, Rubisco can also catalyze the oxygenation reaction of Ribulose-1,5-bisphosphate $(\mathrm{RuBP})$ and $\mathrm{O}_{2}$, that is, the first step of photorespiration that inhibits photosynthesis by consuming light energy and releasing assimilated carbon [45]. The balance of carboxylation and oxygenation reactions depends on the ratio of $\mathrm{O}_{2}$ to $\mathrm{CO}_{2}$ concentration of the site of carboxylation. Elevated $\mathrm{CO}_{2}$ stimulates carboxylation reactions and inhibits oxygenation reaction, promoting the process of photosynthesis. However, the affinity of Rubisco for $\mathrm{CO}_{2}$ and the solubility of $\mathrm{CO}_{2}$ (relative to $\mathrm{O}_{2}$ ) decrease with increasing temperature, thus the increase in temperature will promote photorespiration [48]. The stimulating effect of elevated $\mathrm{CO}_{2}$ on photosynthesis increases with the rising temperature, and $\mathrm{CO}_{2}$ fertilization has a stronger effect with high temperature.

Compared with $\mathrm{C} 3$ plants, elevated $\mathrm{CO}_{2}$ has no direct effect on the photosynthesis of $\mathrm{C} 4$ plants, because $\mathrm{C} 4$ plants have a mechanism which can avoid photorespiration. In FACE experiments, the response of $\mathrm{C} 3$ plants to elevated $\mathrm{CO}_{2}$ is three times that of $\mathrm{C} 4$ plants [44]. Recent studies $[49,50]$ argue that $\mathrm{C} 4$ plants benefit from elevated $\mathrm{CO}_{2}$ indirectly by the interaction of decreased $g_{s}$ and water stress, that is, the drought stress is mitigated by rising $\mathrm{CO}_{2}$-induced higher water use efficiency.

\subsubsection{Photosynthetic Acclimation}

The photosynthetic rate is accelerated by short-term $\mathrm{CO}_{2}$ increases, but plants may eventually adapt to elevated $\mathrm{CO}_{2}$ atmosphere in the long-term. Plants grown in longterm elevated $\mathrm{CO}_{2}$ will experience photosynthetic down-regulation, accompanied by higher concentrations of carbohydrates, lower concentrations of soluble proteins and Rubisco than those grown in the normal ambient atmosphere [4]. The stomatal acclimation to elevated $\mathrm{CO}_{2}$ shows a significant downtrend in stomatal conductance, which is also associated with photosynthetic acclimation [45,51]. Nevertheless, the decline in $g_{s}$ is not considered the dominant reason for the down-regulation of photosynthesis because there is no obvious difference in $\mathrm{Ci} / \mathrm{Ca}$ between plants grown in elevated and ambient $\mathrm{CO}_{2}[4,44]$. The mechanism of acclimation of photosynthesis and stomata behavior is not completely understood, but there are several common possibilities. First, plants are unable to use extra carbohydrates produced by $\mathrm{CO}_{2}$-stimulated photosynthesis, which then trigger the feedback mechanism that inhibits carbohydrate production at the source $[4,45]$. Second, the content and activity of Rubisco decrease under elevated $\mathrm{CO}_{2}[4,52]$. While there is no widespread agreement that photosynthesis will acclimate to elevated $\mathrm{CO}_{2}$, it is hasty to consider photosynthetic acclimation as the eventual result of the plant response to elevated $\mathrm{CO}_{2}$, especially at ecosystem scale.

\subsubsection{Nutrient Availability}

Rubisco requires a large amount of $\mathrm{N}$ investment and the activity of Rubisco play a key role in determining elevated $\mathrm{CO}_{2}$ effects on photosynthesis rate. Therefore, the strength of $\mathrm{CO}_{2}$ fertilization will be greatly reduced when other nutrients such as $\mathrm{N}$ are limited. There have been many experiments and studies supporting the hypothesis that $\mathrm{CO}_{2}$ fertilization is limited by $\mathrm{N}$ availability [53-55]. When the sink strength of plants is limited due to $\mathrm{N}$ restriction, $\mathrm{CO}_{2}$-stimulated excess photosynthate is more likely to trigger the feedback mechanism of plants that reduces products of photosynthesis from the source, thus leading to an earlier occurrence of photosynthetic acclimation [56]. The process of $\mathrm{P}$ affecting forest 
carbon uptake is different from that of $\mathrm{N}$. Ellsworth et al. [57] provide the evidence from FACE experiments that $P$ potentially limits the effect of $\mathrm{CO}_{2}$ fertilization, although their experiment is limited to forests consisting of single species. Terrer et al.'s [58] data analysis of 138 elevated $\mathrm{CO}_{2}$ experiments shows that the strength of elevated $\mathrm{CO}_{2}$ effect on $25 \%$ of global vegetation is primary constrained by $\mathrm{P}$ availability.

\subsection{Ecosystem Responses to Elevated $\mathrm{CO}_{2}$}

Plant physiological response to elevated $\mathrm{CO}_{2}$ at the leaf level has been supported by short-term individual experiments, however, extrapolation of these conclusions from individuals to ecosystems requires multiple data across scales. Over the past decades, research of plant responses to elevated $\mathrm{CO}_{2}$ scaled up and increased in complexity. Largescale open-top chambers (OTC) and FACE experiments with an open-air condition reflect plant responses to elevated $\mathrm{CO}_{2}$ at the field level and extend the timescale of research, however, the incorrect data, experimental deficiencies (such as the unnatural increase of $\mathrm{CO}_{2}$ ) and unsatisfactory future prediction needs still challenge the understanding of global-scale forest responses to climate change.

Satellite observations reveal the change in global vegetation on a scale of decades and there is a documented upward trend on vegetation cover in the northern hemisphere over the past two decades [59]. Recent evidence [60-63] indicates that in recent decades, this trend is probably attributed to a combined effect of the elevated $\mathrm{CO}_{2}$, nutrients, water supply, solar radiation and socio-economic factors (such as land use change and reforestation). For example, according to Nemani et al. [60], global land NPP experienced a climate-induced increase between 1982 and 1999, which is probably due to solar radiation increase rather than $\mathrm{CO}_{2}$ fertilization in the Amazon rainforest (accounting for $42 \%$ of total global NPP increase). Hickler et al. [64] analyze the drivers of the Sahel greening trend through ecosystem modelling and the output suggests that precipitation is the main cause of increased vegetation cover while $\mathrm{CO}_{2}$ has only a small contribution. However, $\mathrm{CO}_{2}$ fertilization is considered more obvious in areas where water is the primary limitation for vegetation growth because the increased WUE under elevated $\mathrm{CO}_{2}$ mitigates water stress [5]. Donohue et al. [5] indicate that the prediction of $\mathrm{CO}_{2}$-stimulated increase in maximum foliage cover is consistent with satellite observations, which suggests that $\mathrm{CO}_{2}$ does play a key role in warm and arid area greening. Ukkola et al. [65] showed consistent results with Donohue et al., and they indicated that the WUE of vegetation in Australia increased over the past decades due to $\mathrm{CO}_{2}$ fertilization. A new method, which scales up from leaf and canopy level, was developed by Ueyama et al. [66] to isolate elevated $\mathrm{CO}_{2}$ effects from other effects and quantify the magnitude of vegetation response globally, and their results supported the effects of $\mathrm{CO}_{2}$ enrichment on GPP increase and transpiration decrease.

Process-based models that involve mechanical process descriptions are feasibly to isolate global forest response to $\mathrm{CO}_{2}$ fertilization from other drivers on a longer time scale (decades). Piao et al.'s [67] modelling studies based on ORCHIDEE suggest that $49 \%$ of the increase of leaf area index (LAI) in growing season in the northern hemisphere is contributed by atmospheric $\mathrm{CO}_{2}$ (temperature and precipitation account for $31 \%$ and $13 \%$, respectively). Ten carbon cycle models used for the IPCC were evaluated through statistical functions by Piao et al. [68] and their results show that every increase of $100 \mathrm{ppm} \mathrm{CO}_{2}$ concentration contributes to $5-20 \%$ simulated NPP increase, which slightly exceeds the results from FACE experiments (13\%). However, Wang et al. [69] indicated a decline in $\mathrm{CO}_{2}$ fertilization effects from 1982 to 2015 based on observation datasets, which related to increased nutrient $(\mathrm{N}, \mathrm{P})$ limitations and water limitation. Their results suggest an overestimation of ecosystem response to elevated $\mathrm{CO}_{2}$ by carbon cycle models, possibly associated to constraint factors, which restrict the ability of ecosystem responses, such as nutrient limitation, photosynthetic acclimation and soil moisture deficit. 


\section{Interaction of Drought and $\mathrm{CO}_{2}$ Fertilization}

Plant responses to elevated $\mathrm{CO}_{2}$ and warming is reflected in the increase of photosynthetic rates and water use efficiency. Recent studies $[49,50,70,71]$ suggest that the $\mathrm{CO}_{2}$ fertilization effect on WUE partly eliminates water limitation during drought events, however, few reports have given explicit quantitative magnitude of the WUE effect. The extent to which extreme events such as drought that negatively affect the ability of vegetation to sequester carbon, and the degree to which the impact of drought can be offset by rising $\mathrm{CO}_{2}$ remains unresolved and debatable. The ecosystem categories and drought intensity and duration are considered to determine the effects of higher water use efficiency on drought resistance. Figure 1 shows the fluxes of carbon and water under elevated $\mathrm{CO}_{2}$ in different levels of drought intensity, exhibiting the responses of forests to diverse droughts.

Reduced stomatal conductance under elevated $\mathrm{CO}_{2}$ may be able to limit water consumption at leaf level (Figure 1b), but the increased evapotranspirating leaf area attributed to rising biomass stimulated by elevated $\mathrm{CO}_{2}$ may offset the effect of $\mathrm{CO}_{2}$-induced stomatal response [72]. The sensitivity coefficient of ecosystem evapotranspiration (ET) to atmospheric $\mathrm{CO}_{2}$ reflects whether biomass growth or lower stomatal conductance dominates ecosystem ET [65]. Ecosystem evapotranspiration response to elevated $\mathrm{CO}_{2}$ may lead to soil moisture and atmospheric humidity variations, which is classified as an indirect response of ecosystems to elevated $\mathrm{CO}_{2}$ [49]. This response varies greatly among ecosystems and species, such that there is not yet a consistent pattern that can describe it.

Evidence from gas exchange chamber experiments suggest that elevated $\mathrm{CO}_{2}$ benefits to water efficiency will initially help resist desiccation. This benefit will gradually disappear under continued drought and heat, as VPD-induced stomatal closure will contribute to loss of $\mathrm{CO}_{2}$ assimilation and increased respiration with leaf temperature leading to $\mathrm{CO}_{2}$ loss (Figure 1c) [6]. The increase in air temperature and desiccation may reverse the $\mathrm{CO}_{2}$-induced WUE increase. Reichstein et al. [73] suggest that the potential possibilities of stomatal closure led to ecosystem water use efficiency decreasing during drought. Although warming and elevated $\mathrm{CO}_{2}$ are expected to benefit plant growth, warming-induced water stress will restrict the positive effects of $\mathrm{CO}_{2}$ fertilization on photosynthesis [70]. Yuan et al. [74] indicate that the terrestrial GPP in the late 1990s experienced a continuous largescale decline, while the vapor pressure deficit increased sharply during the same period, which offset the effect of $\mathrm{CO}_{2}$ fertilization. Silva et al. [70] analyzed temperate and boreal forests in Ontario, Canada, by isotopic and dendrochronological methods, and showed that rising $\mathrm{CO}_{2}$ did increase the water use efficiency, but forest tree growth experienced a widespread decline due to water limitation induced by warming, which suggests that the increase in WUE cannot offset the growth decline under warm drought. A positive case that $\mathrm{CO}_{2}$ fertilization and warming reverses the negative effect of water limitation was found by Morgan et al. [50], who conducted FACE experiments in a semi-arid grassland with C4 grasses. However, their experiments only suggest the effective response of WUE to resist desiccation in grassland and did not cover other vegetation types. Furthermore, drought-induced tree mortality is an essential driver of forest carbon loss. Duan et al. [75] indicated that high temperature accelerates the process of plant hydraulic failure and death and the mitigative effect of elevated $\mathrm{CO}_{2}$ is negligible, but their study is limited to tree seedling mortality.

Therefore, the combined effects of drought and $\mathrm{CO}_{2}$ fertilization depend on the forest's ability to resist water limitation, which leads to whether the biomass growth is stimulated by atmospheric $\mathrm{CO}_{2}$ or lost because of drought-induced tree mortality [18]. There is a concept of the "tipping point" for tropical forests, which indicates that forests will lose their storage carbon sharply when the global daily maximum temperature over the year increases to $32.3^{\circ} \mathrm{C}$, especially in drier forests where water is the primary limitation [18]. 


\section{Conclusions and Outlook}

Although we have recognized that drought events and $\mathrm{CO}_{2}$ fertilization have critical impacts on the carbon cycle of forests, it is still challenging to figure out the complex, comprehensive effects of climate change on vegetation.

We reviewed the current understanding of vegetation response to drought and elevated $\mathrm{CO}_{2}$ from leaf to ecosystem scales. In conclusion, plants initiate drought resistance strategies in arid and warm environments, which likely change the carbon flux of forests. Extreme drought massively killing trees is one of the main reasons for forest ecosystem carbon loss. Elevated $\mathrm{CO}_{2}$ favoring photosynthesis and water use efficiency of plants in a short period of time has been confirmed by a large number of experimental studies, but the effect of $\mathrm{CO}_{2}$ fertilization is limited by other constraint factors such as light, water and nutrients $(\mathrm{N}, \mathrm{P})$. Additionally, on a long-term scale, plants have the possibility of acclimating to warming and elevated $\mathrm{CO}_{2}$ with a lower net photosynthetic assimilation. The underlying mechanism has not been explained clearly. There is great instability and unpredictability in the physiological mechanisms of vegetation adaptation and mortality under drought [76]. This instability stems from the drought resistance of trees and elevated $\mathrm{CO}_{2}$ effects on WUE. However, the problem of how far $\mathrm{CO}_{2}$ fertilization can offset the effects of drought has not been resolved. Whether and to what extent the improved water use efficiency by $\mathrm{CO}_{2}$ fertilization can withstand drought damage remains unknown.

Understanding the interaction effects of rising $\mathrm{CO}_{2}$ and drought is crucial for looking forward to future forest ecosystems growing in a drier and warmer atmosphere. Processbased models are important tools for predicting the future interaction of forest ecosystems and atmosphere, however, accurately extrapolating the conclusions derived from individual experiment reports to large-scale ecosystem models requires more comprehensive observational data and process descriptions. There have been studies that provide information that helps improve model simulations, for example, different vegetation type responses to drought [31,33,42] and N, P limitation [53-55,57,58]. Applying that information to model building may help reduce the uncertainty of models. We recommend considering the uncertainties from the following perspectives:

1. Including observational data across different scales. Flux tower measurements, spacetime data from large-scale long-term experiments, observation of climate change and vegetation change recorded by remote sensing.

2. Different responses to drought among vegetation types and changing plant species composition of ecosystems over time.

3. Consideration of constraint factors. Restrictions of nutritional elements $(\mathrm{N}, \mathrm{P})$, water and light on $\mathrm{CO}_{2}$ fertilization.

4. Effect of photosynthetic acclimation (down-regulation of photosynthetic capacity).

5. Disturbances. The complexity of the multiple disturbance interactions associated with drought (fires, insects and pathogens).

Overall, a better understanding of mechanisms and scale-up methods are key issues in current research on forest strategies to combat climate change. However, it is worth noting that forests cannot infinitely resist climate change, and the containment of greenhouse gases emissions is the fundamental and necessary way of mitigating global warming and protecting forest ecosystem functions.

Author Contributions: Writing—original draft preparation, J.-L.X. and W.-Y.S.; writing-review and editing, F.Z. and W.-Y.S.; help and discussion, F.Z., Q.-L.H., Y.-X.Y., X.H. and W.-Y.S. All authors have read and agreed to the published version of the manuscript.

Funding: This research was funded by National Natural Science Foundation of China (Nos. 41975114 and 41830648).

Institutional Review Board Statement: Not applicable.

Informed Consent Statement: Not applicable. 
Data Availability Statement: No new data were created or analyzed in this study. Data sharing is not applicable to this article.

Conflicts of Interest: The authors declare no conflict of interest.

\section{References}

1. Bonan, G. Forests and climate change: Forcings, feedbacks, and the climate benefits of forests. Science 2008, 320, 1444-1449. [CrossRef]

2. Canadell, J.G.; Raupach, M.R. Managing forests for climate change mitigation. Science 2008, 320, 1456-1457. [CrossRef] [PubMed]

3. Pregitzer, K.S.; Euskirchen, E.S. Carbon cycling and storage in world forests: Biome patterns related to forest age. Glob. Chang. Biol. 2004, 10, 2052-2077. [CrossRef]

4. $\quad$ Drake, B.G.; Gonzàlez-Meler, M.A.; Long, S.P. More efficient plants: A consequence of rising atmospheric $\mathrm{CO}_{2}$ ? Annu. Rev. Plant Biol. 1997, 48, 609-639. [CrossRef]

5. Donohue, R.J.; Roderick, M.L.; McVicar, T.R.; Farquhar, G.D. Impact of $\mathrm{CO}_{2}$ fertilization on maximum foliage cover across the globe's warm, arid environments. Geophys. Res. Lett. 2013, 40, 3031-3035. [CrossRef]

6. Birami, B.; Nagele, T.; Gattmann, M.; Preisler, Y.; Gast, A.; Arneth, A.; Ruehr, N.K. Hot drought reduces the effects of elevated $\mathrm{CO}_{2}$ on tree water-use efficiency and carbon metabolism. New Phytol. 2020, 226, 1607-1621. [CrossRef] [PubMed]

7. Allen, C.D.; Macalady, A.K.; Chenchouni, H.; Bachelet, D.; McDowell, N.; Vennetier, M.; Kitzberger, T.; Rigling, A.; Breshears, D.D.; Hogg, E.H.; et al. A global overview of drought and heat-induced tree mortality reveals emerging climate change risks for forests. For. Ecol. Manag. 2010, 259, 660-684. [CrossRef]

8. Redmond, K.T. The depiction of drought: A commentary. Bull. Am. Meteorol. Soc. 2002, 83, 1143-1148. [CrossRef]

9. Ault, T.R. On the essentials of drought in a changing climate. Science 2020, 368, 256-260. [CrossRef] [PubMed]

10. Slette, I.J.; Post, A.K.; Awad, M.; Even, T.; Punzalan, A.; Williams, S.; Smith, M.D.; Knapp, A.K. How ecologists define drought, and why we should do better. Glob. Chang. Biol. 2019, 25, 3193-3200. [CrossRef]

11. Eslamian, S.; Ostad-Ali-Askari, K.; Singh, V.P. A review of drought indices. Int. J. Constr. Res. Civ. Eng. 2017, 3, 48-66.

12. Smith, M.D. An ecological perspective on extreme climatic events: A synthetic definition and framework to guide future research. J. Ecol. 2011, 99, 656-663. [CrossRef]

13. Reichstein, M.; Bahn, M.; Ciais, P.; Frank, D.; Mahecha, M.D.; Seneviratne, S.I.; Zscheischler, J.; Beer, C.; Buchmann, N.; Frank, D.C.; et al. Climate extremes and the carbon cycle. Nature 2013, 500, 287-295. [CrossRef]

14. Zscheischler, J.; Mahecha, M.D.; Von Buttlar, J.; Harmeling, S.; Jung, M.; Rammig, A.; Randerson, J.T.; Schölkopf, B.; Seneviratne, S.I.; Tomelleri, E.; et al. A few extreme events dominate global interannual variability in gross primary production. Environ. Res. Lett. 2014, 9, 035001. [CrossRef]

15. Gupta, A.; Rico-Medina, A.; Caño-Delgado, A.I. The physiology of plant responses to drought. Science 2020, 368, 266-269. [CrossRef]

16. Granier, A.; Reichstein, M.; Bréda, N.; Janssens, I.A.; Falge, E.; Ciais, P.; Grünwald, T.; Aubinet, M.; Berbigier, P.; Bernhofer, C.; et al. Evidence for soil water control on carbon and water dynamics in European forests during the extremely dry year: 2003. Agric. For. Meteorol. 2007, 143, 123-145. [CrossRef]

17. Huang, C.Y.; Anderegg, W.R.L. Large drought-induced aboveground live biomass losses in southern Rocky Mountain aspen forests. Glob. Chang. Biol. 2011, 18, 1016-1027. [CrossRef]

18. Pennisi, E. Tropical forests store carbon despite warming. Science 2020, 368, 813. [CrossRef] [PubMed]

19. Anderegg, W.R.L.; Trugman, A.T.; Badgley, G.; Anderson, C.M.; Bartuska, A.; Ciais, P.; Cullenward, D.; Field, C.B.; Freeman, J.; Goetz, S.J.; et al. Climate-driven risks to the climate mitigation potential of forests. Science 2020, 368. [CrossRef]

20. McDowell, N.; Pockman, W.T.; Allen, C.D.; Breshears, D.D.; Cobb, N.; Kolb, T.; Plaut, J.; Sperry, J.; West, A.; Williams, D.G.; et al. Mechanisms of plant survival and mortality during drought: Why do some plants survive while others succumb to drought? New Phytol. 2008, 178, 719-739. [CrossRef] [PubMed]

21. Choat, B. Predicting thresholds of drought-induced mortality in woody plant species. Tree Physiol. 2013, 33, 669-671. [CrossRef]

22. Anderegg, W.R.; Berry, J.A.; Smith, D.D.; Sperry, J.S.; Anderegg, L.D.; Field, C.B. The roles of hydraulic and carbon stress in a widespread climate-induced forest die-off. Proc. Natl. Acad. Sci. USA 2012, 109, 233-237. [CrossRef] [PubMed]

23. Ma, Z.; Peng, C.; Zhu, Q.; Chen, H.; Yu, G.; Li, W.; Zhou, X.; Wang, W.; Zhang, W. Regional drought-induced reduction in the biomass carbon sink of Canada's boreal forests. Proc. Natl. Acad. Sci. USA 2012, 109, 2423-2427. [CrossRef]

24. Schwantes, A.M.; Swenson, J.J.; Gonzalez-Roglich, M.; Johnson, D.M.; Domec, J.C.; Jackson, R.B. Measuring canopy loss and climatic thresholds from an extreme drought along a fivefold precipitation gradient across Texas. Glob. Chang. Biol. 2017, 23, 5120-5135. [CrossRef] [PubMed]

25. Sleeter, B.M.; Marvin, D.C.; Cameron, D.R.; Selmants, P.C.; Westerling, A.L.; Kreitler, J.; Daniel, C.J.; Liu, J.; Wilson, T.S. Effects of 21st-century climate, land use, and disturbances on ecosystem carbon balance in California. Glob. Chang. Biol. 2019, 25. [CrossRef]

26. Phillips, O.L.; Aragão, L.E.; Lewis, S.L.; Fisher, J.B.; Lloyd, J.; López-González, G.; Malhi, Y.; Monteagudo, A.; Peacock, J.; Quesada, C.A. Drought sensitivity of the Amazon rainforest. Science 2009, 323, 1344-1347. [CrossRef]

27. Lewis, S.L.; Brando, P.M.; Phillips, O.L.; Van der Heijden, G.M.; Nepstad, D. The 2010 amazon drought. Science 2011, $331,554$. [CrossRef] 
28. Brienen, R.J.; Phillips, O.L.; Feldpausch, T.R.; Gloor, E.; Baker, T.R.; Lloyd, J.; Lopez-Gonzalez, G.; Monteagudo-Mendoza, A.; Malhi, Y.; Lewis, S.L.; et al. Long-term decline of the Amazon carbon sink. Nature 2015, 519, 344-348. [CrossRef]

29. Kljun, N.; Black, T.A.; Griffis, T.J.; Barr, A.G.; Gaumont-Guay, D.; Morgenstern, K.; McCaughey, J.H.; Nesic, Z. Response of net ecosystem productivity of three boreal forest stands to drought. Ecosystems 2007, 10, 1039-1055. [CrossRef]

30. Wolf, S.; Keenan, T.F.; Fisher, J.B.; Baldocchi, D.D.; Desai, A.R.; Richardson, A.D.; Scott, R.L.; Law, B.E.; Litvak, M.E.; Brunsell, N.A.; et al. Warm spring reduced carbon cycle impact of the 2012 US summer drought. Proc. Natl. Acad. Sci. USA 2016, 113, 5880-5885. [CrossRef]

31. Xu, B.; Arain, M.A.; Black, T.A.; Law, B.E.; Pastorello, G.Z.; Chu, H.S. Seasonal variability of forest sensitivity to heat and drought stresses: A synthesis based on carbon fluxes from North American forest ecosystems. Glob. Chang. Biol. 2020, 26. [CrossRef]

32. Angert, A.; Biraud, S.; Bonfils, C.; Henning, C.C.; Buermann, W.; Pinzon, J.; Tucker, C.J.; Fung, I. Drier summers cancel out the $\mathrm{CO}_{2}$ uptake enhancement induced by warmer springs. Proc. Natl. Acad. Sci. USA 2005, 102, 10823-10827. [CrossRef] [PubMed]

33. Welp, L.R.; Randerson, J.T.; Liu, H.P. The sensitivity of carbon fluxes to spring warming and summer drought depends on plant functional type in boreal forest ecosystems. Agric. For. Meteorol. 2007, 147, 172-185. [CrossRef]

34. Von Buttlar, J.; Zscheischler, J.; Rammig, A.; Sippel, S.; Reichstein, M.; Knohl, A.; Jung, M.; Menzer, O.; Arain, M.A.; Buchmann, N.; et al. Impacts of droughts and extreme-temperature events on gross primary production and ecosystem respiration: A systematic assessment across ecosystems and climate zones. Biogeosciences 2018, 15. [CrossRef]

35. Ciais, P.; Reichstein, M.; Viovy, N.; Granier, A.; Ogée, J.; Allard, V.; Aubinet, M.; Buchmann, N.; Bernhofer, C.; Carrara, A Europe-wide reduction in primary productivity caused by the heat and drought in 2003. Nature 2005, 437, 529-533. [CrossRef] [PubMed]

36. Reichstein, M.; Ciais, P.; Papale, D.; Valentini, R.; Running, S.; Viovy, N.; Cramer, W.; Granier, A.; Ogee, J.; Allard, V.; et al. Reduction of ecosystem productivity and respiration during the European summer 2003 climate anomaly: A joint flux tower, remote sensing and modelling analysis. Glob. Chang. Biol. 2007, 13, 634-651. [CrossRef]

37. Lindroth, A.; Holst, J.; Linderson, M.-L.; Aurela, M.; Biermann, T.; Heliasz, M.; Chi, J.; Ibrom, A.; Kolari, P.; Klemedtsson, L.; et al. Effects of drought and meteorological forcing on carbon and water fluxes in Nordic forests during the dry summer of 2018. Philos. Trans. R. Soc. B Biol. Sci. 2020, 375. [CrossRef] [PubMed]

38. Barber, V.A.; Juday, G.P.; Finney, B. Reduced growth of Alaskan white spruce in the twentieth century from temperature-induced drought stress. Nature 2000, 405, 668-673. [CrossRef]

39. Zhou, L.; Tian, Y.; Myneni, R.B.; Ciais, P.; Saatchi, S.; Liu, Y.Y.; Piao, S.; Chen, H.; Vermote, E.F.; Song, C.; et al. Widespread decline of Congo rainforest greenness in the past decade. Nature 2014, 509, 86-90. [CrossRef]

40. Zhang, M.; Yuan, X. Rapid reduction in ecosystem productivity caused by flash droughts based on decade-long FLUXNET observations. Hydrol. Earth Syst. Sci. 2020, 24, 5579-5593. [CrossRef]

41. Gourlez de la Motte, L.; Beauclaire, Q.; Heinesch, B.; Cuntz, M.; Foltynova, L.; Sigut, L.; Kowalska, N.; Manca, G.; Ballarin, I.G.; Vincke, C.; et al. Non-stomatal processes reduce gross primary productivity in temperate forest ecosystems during severe edaphic drought. Philos. Trans. R. Soc. B Biol. Sci. 2020, 375. [CrossRef] [PubMed]

42. Graf, A.; Klosterhalfen, A.; Arriga, N.; Bernhofer, C.; Bogena, H.; Bornet, F.; Brueggemann, N.; Bruemmer, C.; Buchmann, N.; Chi, J.; et al. Altered energy partitioning across terrestrial ecosystems in the European drought year 2018. Philos. Trans. R. Soc. B Biol. Sci. 2020, 375. [CrossRef]

43. Smith, N.E.; Kooijmans, L.M.J.; Koren, G.; Van Schaik, E.; Van der Woude, A.M.; Wanders, N.; Ramonet, M.; Xueref-Remy, I.; Siebicke, L.; Manca, G.; et al. Spring enhancement and summer reduction in carbon uptake during the 2018 drought in northwestern Europe. Philos. Trans. R. Soc. B Biol. Sci 2020, 375. [CrossRef]

44. Ainsworth, E.A.; Long, S.P. What have we learned from 15 years of free-air $\mathrm{CO}_{2}$ enrichment (FACE)? A meta-analytic review of the responses of photosynthesis, canopy properties and plant production to rising $\mathrm{CO}_{2}$. New Phytol. 2005, 165, 351-371. [CrossRef] [PubMed]

45. Ainsworth, E.A.; Rogers, A. The response of photosynthesis and stomatal conductance to rising $\left[\mathrm{CO}_{2}\right]: \mathrm{Mechanisms} \mathrm{and}$ environmental interactions. Plant Cell Environ. 2007, 30, 258-270. [CrossRef]

46. Assmann, S.M. The cellular basis of guard cell sensing of rising $\mathrm{CO}_{2}$. Plant Cell Environ. 1999, 22, 629-637. [CrossRef]

47. Mohr, H.; Schopfer, P. The leaf as a photosynthetic system. In Plant Physiology; Springer: Berlin/Heidelberg, Germany, 1995; pp. 225-243.

48. Long, S.P. Modification of the response of photosynthetic productivity to rising temperature by atmospheric $\mathrm{CO}_{2}$ concentrations: Has its importance been underestimated? Plant Cell Environ. 1991, 14, 729-739. [CrossRef]

49. Morgan, J.A.; Pataki, D.E.; Korner, C.; Clark, H.; Del Grosso, S.J.; Grunzweig, J.M.; Knapp, A.K.; Mosier, A.R.; Newton, P.C.; Niklaus, P.A.; et al. Water relations in grassland and desert ecosystems exposed to elevated atmospheric $\mathrm{CO}_{2}$. Oecologia 2004, 140, 11-25. [CrossRef]

50. Morgan, J.A.; LeCain, D.R.; Pendall, E.; Blumenthal, D.M.; Kimball, B.A.; Carrillo, Y.; Williams, D.G.; Heisler-White, J.; Dijkstra, F.A.; West, M. C4 grasses prosper as carbon dioxide eliminates desiccation in warmed semi-arid grassland. Nature 2011, 476, 202-205. [CrossRef]

51. Xu, D.-Q.; Gifford, R.M.; Chow, W. Photosynthetic acclimation in pea and soybean to high atmospheric $\mathrm{CO}_{2}$ partial pressure. Plant Physiol. 1994, 106, 661-671. [CrossRef] [PubMed] 
52. Da Silva, J.R.; Patterson, A.E.; Rodrigues, W.P.; Campostrini, E.; Griffin, K.L. Photosynthetic acclimation to elevated $\mathrm{CO}_{2}$ combined with partial rootzone drying results in improved water use efficiency, drought tolerance and leaf carbon balance of grapevines. Environ. Exp. Bot. 2017, 134, 82-95. [CrossRef]

53. Norby, R.J.; Warren, J.M.; Iversen, C.M.; Medlyn, B.E.; McMurtrie, R.E. $\mathrm{CO}_{2}$ enhancement of forest productivity constrained by limited nitrogen availability. Proc. Natl. Acad. Sci. USA 2010, 107, 19368-19373. [CrossRef]

54. Reich, P.B.; Hobbie, S.E.; Lee, T.; Ellsworth, D.S.; West, J.B.; Tilman, D.; Knops, J.M.; Naeem, S.; Trost, J. Nitrogen limitation constrains sustainability of ecosystem response to $\mathrm{CO}_{2}$. Nature 2006, 440, 922-925. [CrossRef]

55. Reich, P.B.; Hobbie, S.E.; Lee, T.D. Plant growth enhancement by elevated $\mathrm{CO}_{2}$ eliminated by joint water and nitrogen limitation. Nat. Geosci. 2014, 7, 920-924. [CrossRef]

56. Rogers, A.; Fischer, B.U.; Bryant, J.; Frehner, M.; Blum, H.; Raines, C.A.; Long, S.P. Acclimation of Photosynthesis to Elevated $\mathrm{CO}_{2}$ under Low-Nitrogen Nutrition Is Affected by the Capacity for Assimilate Utilization. Perennial Ryegrass under Free-Air $\mathrm{CO}_{2}$ Enrichment. Plant Physiol. 1998, 118, 683-689. [CrossRef] [PubMed]

57. Ellsworth, D.S.; Anderson, I.C.; Crous, K.Y.; Cooke, J.; Drake, J.E.; Gherlenda, A.N.; Gimeno, T.E.; Macdonald, C.A.; Medlyn, B.E.; Powell, J.R.; et al. Elevated $\mathrm{CO}_{2}$ does not increase eucalypt forest productivity on a low-phosphorus soil. Nat. Clim. Chang. 2017, 7, 279-282. [CrossRef]

58. Terrer, C.; Jackson, R.B.; Prentice, I.C.; Keenan, T.F.; Kaiser, C.; Vicca, S.; Fisher, J.B.; Reich, P.B.; Stocker, B.D.; Hungate, B.A.; et al. Nitrogen and phosphorus constrain the $\mathrm{CO}_{2}$ fertilization of global plant biomass. Nat. Clim. Chang. 2019, 9, 684-689. [CrossRef]

59. Zhou, L.; Tucker, C.J.; Kaufmann, R.K.; Slayback, D.; Shabanov, N.V.; Myneni, R.B. Variations in northern vegetation activity inferred from satellite data of vegetation index during 1981 to 1999. J. Geophys. Res. Atmos. 2001, 106, 20069-20083. [CrossRef]

60. Nemani, R.R.; Keeling, C.D.; Hashimoto, H.; Jolly, W.M.; Piper, S.C.; Tucker, C.J.; Myneni, R.B.; Running, S.W. Climate-driven increases in global terrestrial net primary production from 1982 to 1999. Science 2003, 300, 1560-1563. [CrossRef] [PubMed]

61. Donohue, R.J.; McVicar, T.R.; Roderick, M.L. Climate-related trends in Australian vegetation cover as inferred from satellite observations, 1981-2006. Glob. Chang. Biol. 2009, 15, 1025-1039. [CrossRef]

62. Fensholt, R.; Langanke, T.; Rasmussen, K.; Reenberg, A.; Prince, S.D.; Tucker, C.; Scholes, R.J.; Le, Q.B.; Bondeau, A.; Eastman, R.; et al. Greenness in semi-arid areas across the globe 1981-2007-An Earth Observing Satellite based analysis of trends and drivers. Remote Sens. Environ. 2012, 121, 144-158. [CrossRef]

63. Keenan, T.F.; Prentice, I.C.; Canadell, J.G.; Williams, C.A.; Wang, H.; Raupach, M.; Collatz, G.J. Recent pause in the growth rate of atmospheric $\mathrm{CO}_{2}$ due to enhanced terrestrial carbon uptake. Nat. Commun. 2016, 7, 13428. [CrossRef]

64. Hickler, T.; Eklundh, L.; Seaquist, J.W.; Smith, B.; Ardö, J.; Olsson, L.; Sykes, M.T.; Sjöström, M. Precipitation controls Sahel greening trend. Geophys. Res. Lett. 2005, 32. [CrossRef]

65. Ukkola, A.M.; Prentice, I.C.; Keenan, T.F.; Van Dijk, A.I.J.M.; Viney, N.R.; Myneni, R.B.; Bi, J. Reduced streamflow in water-stressed climates consistent with $\mathrm{CO}_{2}$ effects on vegetation. Nat. Clim. Chang. 2016, 6, 75-78. [CrossRef]

66. Ueyama, M.; Ichii, K.; Kobayashi, H.; Kumagai, T.O.; Beringer, J.; Merbold, L.; Euskirchen, E.S.; Hirano, T.; Marchesini, L.B.; Baldocchi, D.; et al. Inferring $\mathrm{CO}_{2}$ fertilization effect based on global monitoring land-atmosphere exchange with a theoretical model. Environ. Res. Lett. 2020, 15, 084009. [CrossRef]

67. Piao, S.; Friedlingstein, P.; Ciais, P.; Zhou, L.; Chen, A. Effect of climate and $\mathrm{CO}_{2}$ changes on the greening of the Northern Hemisphere over the past two decades. Geophys. Res. Lett. 2006, 33. [CrossRef]

68. Piao, S.; Sitch, S.; Ciais, P.; Friedlingstein, P.; Peylin, P.; Wang, X.; Ahlstrom, A.; Anav, A.; Canadell, J.G.; Cong, N.; et al. Evaluation of terrestrial carbon cycle models for their response to climate variability and to $\mathrm{CO}_{2}$ trends. Glob. Chang. Biol. 2013, 19. [CrossRef] [PubMed]

69. Wang, S.; Zhang, Y.; Ju, W.; Chen, J.M.; Ciais, P.; Cescatti, A.; Sardans, J.; Janssens, I.A.; Wu, M.; Berry, J.A.; et al. Recent global decline of $\mathrm{CO}_{2}$ fertilization effects on vegetation photosynthesis. Science 2020, 370, 1295-1300. [CrossRef]

70. Silva, L.C.; Anand, M.; Leithead, M.D. Recent widespread tree growth decline despite increasing atmospheric $\mathrm{CO}_{2}$. PLoS ONE 2010, 5, e11543. [CrossRef] [PubMed]

71. Sangines de Carcer, P.; Vitasse, Y.; Penuelas, J.; Jassey, V.E.J.; Buttler, A.; Signarbieux, C. Vapor-pressure deficit and extreme climatic variables limit tree growth. Glob. Chang. Biol. 2018, 24, 1108-1122. [CrossRef]

72. Piao, S.; Friedlingstein, P.; Ciais, P.; De Noblet-Ducoudré, N.; Labat, D.; Zaehle, S. Changes in climate and land use have a larger direct impact than rising $\mathrm{CO}_{2}$ on global river runoff trends. Proc. Natl. Acad. Sci. USA 2007, 104, 15242-15247. [CrossRef]

73. Reichstein, M.; Tenhunen, J.D.; Roupsard, O.; Ourcival, J.M.; Rambal, S.; Miglietta, F.; Peressotti, A.; Pecchiari, M.; Tirone, G.; Valentini, R. Severe drought effects on ecosystem $\mathrm{CO}_{2}$ and $\mathrm{H}_{2} \mathrm{O}$ fluxes at three Mediterranean evergreen sites: Revision of current hypotheses? Glob. Chang. Biol. 2002, 8, 999-1017. [CrossRef]

74. Yuan, W.; Zheng, Y.; Piao, S.; Ciais, P.; Lombardozzi, D.; Wang, Y.; Ryu, Y.; Chen, G.; Dong, W.; Hu, Z. Increased atmospheric vapor pressure deficit reduces global vegetation growth. Sci. Adv. 2019, 5, eaax1396. [CrossRef]

75. Duan, H.; Duursma, R.A.; Huang, G.; Smith, R.A.; Choat, B.; O'Grady, A.P.; Tissue, D.T. Elevated $\left[\mathrm{CO}_{2}\right]$ does not ameliorate the negative effects of elevated temperature on drought-induced mortality in Eucalyptus radiata seedlings. Plant Cell Environ. 2014, 37. [CrossRef] [PubMed]

76. Jump, A.S.; Ruiz-Benito, P.; Greenwood, S.; Allen, C.D.; Kitzberger, T.; Fensham, R.; Martínez-Vilalta, J.; Lloret, F. Structural overshoot of tree growth with climate variability and the global spectrum of drought-induced forest dieback. Glob. Chang. Biol. 2017, 23, 3742-3757. [CrossRef] [PubMed] 